\title{
The Tax Injunction Act and Suits for Monetary Relief
}

Section 1341 of Title 28 of the United States Code 1 - frequently referred to as the Tax Injunction Act-bars suits in federal court to "enjoin, suspend or restrain" collection of state or local ${ }^{2}$ taxes, except where no "plain, speedy and efficient remedy" is available in state court. ${ }^{3}$ That the Act comprehends suits for equitable relief is settled; its applicability to actions for monetary judgment has, however, remained uncertain.

Federal court actions seeking monetary relief from state or local taxes fall into two categories: damage actions and refund suits. Refund suits, which provide for the restitution of money paid to satisfy an illegally levied tax, arise under state statute ${ }^{4}$ or common law. ${ }^{5}$ Damage actions may be based on either state or federal reme-

' Section 1341 provides: "The district courts shall not enjoin, suspend or restrain the assessment, levy or collection of any tax under State law where a plain, speedy and efficient remedy may be had in the courts of such State." 28 U.S.C. § 1341 (1976).

2 Section 1341's protection is directed at taxes imposed "under State law." Id. Since local taxes are assessed under authority of state law, the section applies to local as well as state levies. 17 C. Wright, A. Miller \& E. Cooper, Federal Practice and Procedure $§ 4237$, at 418 (1978). See, e.g., Soo Line R.R. v. City of Harvey, 424 F. Supp. 329, 330 (D.N.D. 1976) ("special assessment levied by a municipal corporation against a railroad is a tax within the meaning of this section").

3 The Supreme Court in several decisions used the word "adequate" interchangeably with the phrase "plain, speedy and efficient." Township of Hillsborough v. Cromwell, 326 U.S. 620, 624 (1946); Spector Motor Serv., Inc. v. McLaughlin, 323 U.S. 101, 106 (1944). It has thus been suggested that the standard of " 'plain, speedy and efficient' means no more than the prior equity standard of 'adequacy.' " Garrett v. Bamford, 538 F.2d 63, 67 (3d Cir.), cert. denied, 429 U.S. 977 (1976); see P. Bator, P. Mishkin, D. Shapiro \& H. WechsLer, HarT \& Wechsler's The Federal Courts and the Federal System 979 (2d ed. 1973) [hereinafter cited as Hart \& Wechsler]; C. Wright, HandBook of THE LaW of Federal Courts $\S 51$, at 216-17 (3d ed. 1976). Several commentators have argued, however, that Congress intended the statutory requirement to be a stricter one. E.g., Note, Federal Court Interference with the Assessment and Collection of State Taxes, 59 HaRv. L. REv. 780, 784 (1946) [hereinafter cited as Harvard Note]; Note, Jurisdiction to Enforce Federal Statutes Regulating State Taxation: The Eleventh Amendment-Section 1341 Imbroglio, 70 YaLE L.J. 636, 643 \& n.47 (1961) [hereinafter cited as Yale Note].

- Many state statutes expressly create a cause of action for the refund of state or local taxes. See, e.g., ARK. Stat. Ann. \& 84-2038 (1960); CaL. Rev. \& Tax. Code $\$ 5140$ (West Supp. 1979); Kan. Stat. ANN: $\$ 79-2005$ (1977). Where such a remedy is not expressly granted, but the taxing body is under a duty to refund any illegal or erroneous tax, the courts are likely to imply "a correlative right to enforce that duty by an action at law." Singer Sewing Mach. Co. v. Benedict, 229 U.S. 481, 486 (1913).

5 At common law, a taxpayer could sue for a refund of taxes that were "involuntarily paid under protest... when there was no jurisdiction. to assess the taxes sought to be recovered." City of Franklin v. Coleman Bros. Corp., 152 F.2d 527, 531 (1st Cir. 1945), cert. denied, 328 U.S. 844 (1946). The opportunity to institute a common-law action for a tax refund now depends on the particular state or local statute governing tax refunds. Where the 
dial statutes. In the most common form of damage action, a taxpayer who contends that state or local taxes have been collected from him in contravention of the fourteenth amendment brings a section 1983 suit $^{b}$ in federal court for damages against the tax collector in his official or individual capacity, ${ }^{7}$ or, in some cases, against the governmental unit itself. ${ }^{8}$ The taxpayer may institute suit even before paying the allegedly unlawful taxes if he has been injured as

statutory remedy is not an exclusive one, a taxpayer may still bring a refund suit based on a common-law right. See, e.g., District of Columbia v. Brady, 288 F.2d 108, 110 (D.C. Cir. 1960). See also Texas \& Pac. Ry. v. Abilene Cotton Oil Co., 204 U.S. 426 (1907).

- 42 U.S.C. $\$ 1983$ (1976) (creating federal cause of action against persons who, under color of state law, deprive another of "rights, privileges, or immunities secured by the Constitution and laws"). For examples of section 1983 tax-related damage actions, see Fulton Mkt. Cold Storage Co. v. Cullerton, 582 F.2d 1071 (7th Cir. 1978), cert. denied, 99 S. Ct. 1033 (1979); Bland v. McHann, 463 F.2d 21 (5th Cir. 1972), cert. denied, 410 U.S. 966 (1973); Evangelical Catholic Communion, Inc. v. Thomas, 373 F. Supp. 1342 (D. Vt. 1973), aff'd mem., 493 F.2d 1397 (2d Cir. 1974).

${ }^{7}$ A damage suit against a state official in his official capacity may be regarded as a suit against the state and thus barred by the eleventh amendment, which provides that the "Judicial power of the United States shall not be construed to extend to any suit in law or equity . . . against one of the United States by Citizens of another State." U.S. ConST. amend. XI. See Edelman v. Jordan, 415 U.S. 651 (1974). The amendment does"not, however, preclude suits for money damages against state officers in their personal capacities "so long as the judgment will not operate on its face to force a recovery directly from the state treasury." Developments in the Law-Section 1983 and Federalism, 90 Harv. L. Rev. 1133, 1196 (1977) (footnote omitted) [hereinafter cited as Developments]. See, e.g., Edelman v. Jordan, 415 U.S. 651, 664-71 (1974); Scheuer v. Rhodes, 416 U.S. 232, 237-38 (1974). At least one court has suggested that when the state indemnifies the officer, the eleventh amendment should bar the suit. Hallmark Clinic v. North Carolina Dep't of Human Resources, $380 \mathrm{~F}$. Supp. 1153, 1159 \& n.12, 1160 (E.D.N.C. 1974) (three-judge court). But see Tribe, Intergovernmental Immunities in Litigation, Taxation, and Regulation: Separation of Powers Issues in Controversies About Federalism, 89 HaRv. L. REv. 682, 686 n.25 (1976).

8 Most suits against the state, or suits that will require payment of funds from the state treasury, will be barred by the eleventh amendment. The Supreme Court has interpreted the amendment, contrary to its literal meaning, to bar suits brought against a state by its own citizens. Hans v. Louisiana, 134 U.S. 1 (1890). The Court has also held, apparently contrary to the jurisdictional nature of the eleventh amendment bar, that a state may be sued in federal court if it consents to the suit. See id. at 21 (Harlan, J., concurring); Clark v. Barnard, 108 U.S. 436, 447 (1883). Moreover, a state may be sued under a federal statute if there is a "clear statement" of Congress's intent to make the state amenable to suit. See Employees of Dep't of Pub. Health \& Welfare v. Department of Pub. Health \& Welfare, 411 U.S. 279, 28487 (1973). A state also need not consent to suit when Congress has acted pursuant to its enforcement power under the fourteenth amendment. See Fitzpatrick v. Bitzer, 427 U.S. 445, 456 (1976) (state sovereignty principle embodied in eleventh amendment limited by enforcement provision of fourteenth amendment). But there must still be the "threshold fact of congressional authorization" for such suits. Id. at 452 (quoting Edelman v. Jordan, 415 U.S. $651,672(1974))$. The Court has stated, however, that in passing the Act that is now section 1983, Congress did not intend to include states within the class of defendants reached by the statute. Quern v. Jordan, 99 S. Ct. 1139, 1144-47 (1979) (dictum). Thus, a state may be sued for damages under section 1983 only with its consent. 
a result of his nonpayment' or the government's attempted collection $^{10}$ of the taxes. Although the result of such damage actions is not an injunction against collection of the disputed taxes, the outcome often turns on a determination of the lawfulness of the assessment." ${ }^{11}$

The federal courts are divided over whether, and under what circumstances, the Tax Injunction Act should be construed to deprive plaintiffs of a federal forum for damage actions against state and local taxing authorities. The courts have often relied on the form of the action-whether it is brought under a generally applicable remedial statute or a specific refund authorization-to determine the applicability of the Tax Injunction Act. Thus, in the relatively small number of cases involving state-law refund claims, the courts have consistently found the Tax Injunction Act inapplicable. ${ }^{12}$ But most courts have reached the opposite result with respect to refund-type damage actions. ${ }^{13}$ This comment proposes an alternative approach to the Tax Injunction Act. After examining the Act's legislative history and the development of its application by the courts, the comment argues for an impact approach to actions for monetary judgment. This approach to section 1341 will effectuate the dominant congressional objective underlying the statute by imposing a jurisdictional bar to those actions that disrupt the continuity of state and local tax collection.

The eleventh amendment's bar does not extend to political subdivisions of the state. Lincoln County v. Luning, 133 U.S. 529, 530 (1890). Until recently, however, plaintiffs could not bring section 1983 suits against counties or municipalities because of the Supreme Court's holding that municipalities were not "persons" for purposes of section 1983. Monroe v. Pape, 365 U.S. 167 (1961). The Court recently reversed this portion of Monroe in Monell v. Department of Social Servs., 436 U.S. 658 (1978), thus allowing section 1983 suits against municipalities, or other political subdivisions of the state, for damages directly or indirectly caused by the municipality. Id. at 690-91.

- For example, a taxpayer's failure to pay property taxes may result in a tax lien on the property, the consequences of which may be a reduced selling price for-or inability to even sell-the property, or an inability to borrow against the property.

${ }^{10}$ See, e.g., Ludwin v. City of Cambridge, 592 F.2d 606 (1st Cir. 1979); Advertiser Co. v. Wallace, 446 F. Supp. 677 (M.D. Ala. 1978).

"See Evangelical Catholic Communion, Inc. v. Thomas, 373 F. Supp. 1342, 1344 (D. Vt. 1973), aff'd mem., 493 F.2d 1397 (2d Cir. 1974).

12 See, e.g., Georgia Pac. Corp. v. County of Mendocino, 340 F. Supp. 1061 (N.D. Cal. 1972); Rico Argentine Mining Co. v. Board of County Comm'rs, 215 F. Supp. 208 (D. Colo. 1963); cf. Ott v. De Bardeleben Coal Corp., 166 F.2d 509 (5th Cir. 1948) (permitting statelaw refund actions with no mention of Act of 1937), rev'd on other grounds sub nom. Ott v. Mississippi Valley Barge Line Co., 336 U.S. 169 (1949).

${ }^{13}$ See text and notes at notes $96-99$ and note 110 infra. 


\section{Legislative History of Section 1341}

\section{A. Congressional Purposes}

Section 1341 was originally enacted as the Tax Injunction Act of 1937. ${ }^{14}$ Both courts ${ }^{15}$ and commentators ${ }^{16}$ have agreed that the Act was part of a broad congressional response to the increased exposure of state officials to suits for injunctive relief after Ex parte Young. ${ }^{17}$ The courts have also cited two specific policy considerations, set forth in the Senate Judiciary Committee Report on the Act of 1937, 18 that prompted Congress to create the tax-injunction bar. First, Congress acted out of a desire to eliminate the perceived discrimination against state citizens who did not share the ability of foreign corporations to obtain prospective relief from unlawful state and local taxes in federal court. Second, Congress feared that use of diversity jurisdiction by foreign corporations to enjoin collection of taxes would seriously disrupt the fiscal stability of state and local governments. ${ }^{19}$ Although the courts have generally regarded the congressional purposes behind the Act of 1937 as obvious, ${ }^{20}$ a close examination of the legislative history suggests that the Act reflected a more complex legislative intent.

1. Response to Ex parte Young. The Supreme Court's 1908 decision in Ex parte Young upheld, despite the eleventh amendment, a contempt order against the Attorney General of Minnesota for violating an injunction prohibiting him from enforcing a newly enacted statute reducing railroad rates. The Court reasoned that the

14 Act of Aug. 21, 1937, ch. 726, 50 Stat. 738 (current version at 28 U.S.C. $\$ 1341$ (1976)) [hereinafter cited as Act of 1937]. The language of the statute has undergone only inconsequential changes since its enactment.

${ }_{15}$ See, e.g., Fulton Mkt. Cold Storage Co. v. Cullerton, 582 F.2d 1071, 1074 (7th Cir. 1978), cert. denied, 99 S. Ct. 1033 (1979); Garrett v. Bamford, 538 F.2d 63, 66 (3d Cir.), cert. denied, 429 U.S. 977 (1976); Hargrave v. McKinney, 413 F.2d 320, 325 (5th Cir. 1969).

1" See, e.g., 17 C. WRight, A. MnLER \& E. Cooper, supra note 2, § 4236, at 407-08, § 4237, at 415; Pratt, How to Use Federal Courts to Enjoin the Collection of State and Local Taxes, 46 J. Tax. 178, 178 (1977).

17209 U.S. 123 (1908). Other enactments of that era characterized as responses to $E x$ parte Young are the Johnson Act, ch. 283,48 Stat. 775 (1934) (current version at 28 U.S.C. § 1342 (1976)); the stay-requirement provision of the Act of Mar. 4, 1913, ch. 160, $\$ 266,37$ Stat. 1013 (repealed 1976); and the three-judge provision of the Act of Mar. 3, 1911, ch. 231, $\S 266,36$ Stat. 1162 (repealed 1976).

is S. REp. No. 1035, 75th Cong., 1st Sess. 1-2 (1937).

" See Fulton Mkt. Cold Storage Co. v. Cullerton, 582 F.2d 1071, 1074-75 (7th Cir. 1978), cert. denied, 99 S. Ct. 1033 (1979); Garrett v. Bamford, 538 F.2d 63, 66 (3d Cir.), cert. denied, 429 U.S. 977 (1976); Tramel v. Schrader, 505 F.2d 1310, 1315-16 (5th Cir. 1975).

see, e.g., Department of Employment v. United States, 385 U.S. 355, 358 (1966) ("convincing evidence of legislative purpose") (footnote omitted); Garrett v. Bamford, 538 F.2d 63, 66 (3d Cir.) ("Congressional materials revealing the purposes of the Tax Injunction Act are brief but clear"), cert. denied, 429 U.S. 977 (1976). 
Attorney General's action as a state officer was stripped of its official character by the unconstitutionality of the law that he was attempting to enforce. Ex parte Young thus opened the federal courts to attacks on unconstitutional action of state officials by plaintiffs seeking injunctive relief and "brought about a major shift in the actual distribution of power between states and nation."'21

The Ex parte Young decision probably accounts for the willingness of Congress to enact legislation such as the Tax Injunction Act, but it cannot serve as the sole explanation for the enactment. The scope of the Act of 1937 was in some respects narrower and in others broader than the decision in Ex parte Young. It did not completely obliterate the legacy of that decision in the context of tax-injunction suits against states; it created only a conditional bar to such suits. If the plaintiff could not obtain a "plain, speedy, and efficient remedy" in the state courts, the Act allowed an action to be brought in a federal forum. ${ }^{22}$ The Act also barred all suits "to enjoin, suspend, or restrain the assessment, levy, or collection of any tax imposed by or pursuant to the laws of any State." ${ }^{23}$ As a result, it reached suits against counties and municipalities as well as those against state officials, since local taxes are imposed under state law. ${ }^{24}$ County and municipal officials had never enjoyed eleventh amendment protection. ${ }^{25}$ The broad sweep of the Act therefore effected more than a simple reestablishment of eleventh amendment protection afforded states prior to Ex parte Young. Finally, section 1341 foreclosed a class of federal suits against state officials that long prior to $E x$ parte Young had been outside the eleventh amendment bar: actions to enjoin state tax officials from collecting taxes imposed in contravention of the Constitution or of state statutory or common law, if the taxpayer had no adequate remedy at law. ${ }^{26}$ Although section 1341 applies to suits brought under the rationale of Ex parte Young, its scope contradicts any general assertion that Congress intended the Act of 1937 simply to minimize the effects of that decision.

${ }^{21}$ Hart \& Wechsler, supra note 3 , at 965 .

2 Act of 1937, ch. 726, 50 Stat. 738 (current version at 28 U.S.C. $\S 1341$ (1976)).

${ }^{23} \mathrm{Id}$. (emphasis added).

${ }^{24}$ See note 2 supra.

${ }^{25}$ See note 8 supra.

2s 1 C. Bates, Federal Equity Procedure $\$ 546$ (1901). For examples, see Ogden City v. Armstrong, 168 U.S. 224 (1897); Allen v. Baltimore \& O.R.R., 114 U.S. 331 (1885). See also Shelton v. Platt, 139 U.S. 591 (1891) (equity jurisdiction denied because plaintiff had adequate remedy at law); Dows v. Chicago, 78 U.S. 108 (1870) (same). 
2. Discrimination Against Resident Plaintiffs. Courts that have examined the legislative history of section 1341 have focused on the most conspicuous aspect of that history: "Congress' apparent concern to limit the ability of foreign corporations to use the diversity jurisdiction"' ${ }^{27}$ to seek injunctions against state taxes in the federal courts. Such diversity suits troubled Congress in part because of the discrimination between state citizens and foreign corporations. Both the House and Senate committee reports noted "the highly unfair picture . . . of the citizen of the State being required to pay first and then litigate," while those plaintiffs who could meet the federal jurisdictional requirements could withhold payment of part or all of the taxes during the period of litigation. ${ }^{28}$ Although obviously of concern to Congress, the problem of discrimination posed by diverse plaintiffs suing in federal court to enjoin state tax collection also fails to account for the expansive language of the Act, which by its terms is equally applicable to suits brought under diversity or federal question jurisdiction. The paradigm of the latter variety is the Ex parte Young-type suit discussed above. If discrimination against in-state plaintiffs was the principal concern of the congressional draftsmen, the Act as finally conceived was overbroad.

3. Disruption of State and Local Tax Collection. A congressional purpose that better explains the scope of the Tax Injunction Act's conditional denial of federal jurisdiction can be identified in the general federal policy of noninterference with state taxing procedures. ${ }^{29}$ Concern about the effects of federal court interference with

${ }^{27}$ Garrett v. Bamford, 538 F.2d 63, 67 (3d Cir.) (emphasis in original), cert. denied, 429 U.S. 977 (1976); see Fulton Mkt. Cold Storage Co. v. Cullerton, 582 F.2d 1071, 1074-75 (7th Cir. 1978), cert. denied, 99 S. Ct. 1033 (1979); ALCOA v. Department of Treasury, 522 F.2d 1120, 1124 (6th Cir. 1975); Hargrave v. McKinney, 413 F.2d 320, 325-26 (5th Cir. 1969). The court in Garrett $v$. Bamford suggested that suits brought under diversity rather than federal question jurisdiction were the only concern of Congress. 538 F.2d at 66-67. For discussions of the Garrett decision, see 15 DuQ. L. Rev. 295 (1977); 90 Harv. L. Rev. 616 (1977).

${ }_{23}$ H.R. Rep. No. 1503, 75th Cong., 1st Sess. 2 (1937); S. REp. No. 1035, 75th Cong., 1st Sess. 2 (1937); see 81 Cong. REC. 1415, 1416 (1937) (remarks of Sen. Bone). See also note 37 infra.

2) See Perez v. Ledesma, 401 U.S. 82, 128 n.17 (1971) (Brennan, J., concurring in part, dissenting in part):

The special reasons justifying the policy of federal noninterference with state tax collection are obvious. The procedures for mass assessment and collection of state taxes and for administration and adjudication of taxpayers' disputes with tax officials are generally complex and necessarily designed to operate according to established rules. State tax agencies are organized to discharge their responsibilities in accordance with state procedures. If federal declaratory relief were available to test state tax assessments, state tax administration might be thrown into disarray, and taxpayers might escape the ordinary procedural requirements imposed by state law. During the pendency of the 
state tax collection had the attention of federal courts long before the enactment of section 1341. Relying on the general statutory limitation on federal equity jurisdiction,,$^{30}$ the courts had refused to exercise their equitable jurisdiction in suits to enjoin state tax collection if an adequate remedy at law existed. ${ }^{31}$ Although the cases left some doubt whether the prohibition extended to cases in which there was an adequate state remedy or only cases in which the federal legal remedy was adequate,,$^{32}$ the cases rested upon a policy of special deference to state tax collection..$^{33}$ In Matthews $v$. Rodgers, decided five years before Congress enacted the Tax Injunction Act, the Supreme Court announced that federal courts would not enjoin state tax collection when adequate state legal remedies existed. Where such a remedy was available, the Matthews Court stressed, "scrupulous regard for the rightful independence of state governments" and "reluctance to interfere by injunction with [state] fiscal operations" required federal courts to refuse equitable relief..$^{34}$

The legislative history of the Act of 1937 evidences a similar concern with protecting state tax procedures from federal interference. Both the Senate and House reports on the bill that became the Tax Injunction Act emphasized that suits brought in federal courts by foreign corporations for injunctive relief from state or local taxes disrupted the continuous flow of governmental revenues. ${ }^{35}$

federal suit the collection of revenue under the challenged law might be obstructed, with consequent damage to the State's budget . . . .

${ }^{30}$ Judiciary Act of 1789 , ch. $20, \S 16,1$ Stat. 82 (repealed 1911) (federal equity jurisdiction was lacking "in any case where plain, adequate and complete remedy may be had at law").

${ }^{31}$ See, e.g., Singer Sewing Mach. Co. v. Benedict, 229 U.S. 481 (1913); Boise Artesian Hot \& Cold Water Co. v. Boise City, 213 U.S. 276 (1909); Arkansas Bldg. \& Loan Ass'n v. Madden, 175 U.S. 269 (1899); Dows v. City of Chicago, 78 U.S. 108 (1870).

${ }^{32}$ Compare Matthews v. Rodgers, 284 U.S. 521 (1932) and Indiana Mfg. Co. v. Koehne, 188 U.S. 681 (1903) with Henrietta Mills v. Rutherford County, 281 U.S. 121, 126-28 (1930), Risty v. Chicago, R.I. \& P. Ry., 270 U.S. 378, 388 (1926), and Chicago, B. \& O.R.R. v. Osborne, 265 U.S. 14, 16 (1924). The confusion seems to be the result, in part, of Chief Justice Stone's attempt to exadicate the notion that "adequacy of legal remedies" was jurisdictionally based-therefore requiring adequate federal legal remedies-in favor of a discretionary abstention doctrine based upon the adequacy of state or federal legal remedies. See, e.g., Great Lakes Dredge \& Dock Co. v. Huffman, 319 U.S. 293 (1943) (Stone, C.J.); Matthews v, Rodgers, 284 U.S. 521 (1932) (Stone, J.). See generally Z. ChafeE, JR., Some Problems of EQUTYY 321-26 (1950).

- The Matthews Court purported to rely on established federal statutory and judicial limitations on equitable jurisdiction. 284 U.S. at 525-26. It has since been treated as announcing a special rule of equitable abstention for state-tax cases. See Yale Note, supra note 3, at 642-43.

33 See Singer Sewing Mach. Co. v. Benedict, 229 U.S. 481, 485 (1913).

34 U.S. at 525. The Matthews Court echoed a concern expressed sixty years earlier in Dows v. Chicago, 78 U.S. 108, 110 (1870).

${ }^{35}$ H.R. REP. No. 1503, 75th Cong., 1st Sess. 2 (1937); S. REP. No. 1035, 75th Cong., 1st 
State laws, on the other hand, generally did not permit taxpayers to contest their taxes-state or local-until the taxes had been paid. ${ }^{36} \mathrm{~A}$ suit by a taxpayer in state court, as an action for a refund, does not disrupt the continuous collection of revenues because the taxing authority has the disputed revenues at its disposal during the pendency of the action. Availability of anticipatory relief in federal court, however, undermines the state procedures designed to maintain the flow of revenue to state and local governments. ${ }^{37}$ The enacting Congress noted further that the disruptive effect of federal court suits brought prior to payment of the challenged taxes induced compromises by tax officials that would not have resulted if the suits were limited to state courts and procedures:

The pressing needs of these States for this tax money is so great that in many instances they have been compelled to compromise these suits, as a result of which substantial portions of the tax have been lost to the States without a judicial examination into the real merits of the controversy..$^{38}$

The legislative history suggests that although federalism con-

Sess. 2 (1937) (foreign corporations able to "withhold from [states] and their governmental subdivisions taxes, in such vast amounts and for such long periods of time as to seriously disrupt State and county finances").

${ }^{36}$ H.R. REP. No. 1503, 75th Cong., 1st. Sess. 2 (1937); S. REP. No. 1035, 75th Cong., 1st Sess. 2 (1937).

$\pi$ This effect was mitigated somewhat by the federal equity requirement that a taxpayer suing to enjoin a state tax must first pay that part of the tax conceded to be due. See $1 \mathrm{C}$. BATEs, supra note $26, \S 546$, at 554 . But in practice this rule meant that plaintiffs who could otherwise satisfy the federal jurisdiction requirement needed only to "pay what they choose and withhold the balance during the period of litigation." S. REP. No. 1035, 75th Cong., 1st Sess. 2 (1937).

State-law procedural requirements for challenging state or local taxes did not affect suits in federal court since at the time the Tax Injunction Act was enacted, Supreme Court doctrine stated that federal equity jurisdiction could neither be expanded nor contracted by state law. Mason v. United States, 260 U.S. 545, 557 (1923). The following year, however, the Supreme Court decided Erie R.R. v. Tompkins, 304 U.S. 64 (1938). Erie held that in suits brought in diversity, the federal courts were bound to apply state decisional law as well as to follow state statutes. Id. at 78. By its terms, the Erie decision did away with "federal general common law." Id. The question arises in the context of tax-injunction suits whether a federal court of equity, in a diversity suit, is limited to granting relief that would be available in state court. The authorities are divided on the issue. Compare Clark Equip. Co. v. Armstrong Equip. Co., 431 F.2d 54, 57 (5th Cir. 1970) (Erie does not limit federal equity court), cert. denied, 402 U.S. 909 (1971) with 2 Moore's FrDERAL PraCTICE If 2.09, at 454-55 (2d ed. 1979) (Erie demands federal equity court give only remedy available in state court). If Erie does so limit federal equity power, and if the scope of section 1341 were limited to what Congress identified as the primary problem addressed by the Act of 1937, see text and note at note 28 supra, the Act would have been largely mooted just one year after its enactment.

${ }^{38}$ H.R. ReP. No. 1503, 75th Cong., 1st Sess. 2 (1937); S. ReP. No. 1035, 75th Cong., 1st Sess. 2 (1937). 
cerns raised by federal courts entertaining challenges to state taxes were important, Congress was more acutely concerned with the practical impact such suits could have on the financial stability of state and local governments. ${ }^{39}$ What may have prompted Congress to act, despite the limitations on federal equity jurisdiction already recognized by the courts, was the narrow construction given by the federal courts to "adequate" remedies at law" and their resulting failure to cut back sufficiently on tax-injunction suits. ${ }^{41}$ The rationale of the Tax Injunction Act-preservation of the fiscal integrity of state and local governments-is broader than the particular problems engendered by the Ex parte Young doctrine or the "discriminatory" effect of foreign corporations' use of diversity jurisdiction to avoid paying their taxes. Congress sought to prevent those suits in federal court that would have a disruptive impact on the processes of state and local revenue collection. An awareness of this principle is crucial in reaching a conclusion about the applicability of the Act to damage actions. A perception that Congress was merely responding to Ex parte Young or to diversity suits invites a focus on the form of an action-whether injunctive or otherwise, brought under diversity or federal question jurisdiction-rather than its impact, in order to determine whether it falls within the prohibition of section 1341. Such a formalistic approach does not comport with the policy underlying the statute.

\section{B. The Causes of Action Congress Intended Section 1341 to Govern}

The legislative history does not clearly indicate which actions Congress intended the Act to reach. Whether Congress intended the phrase "suits to enjoin, suspend, or restrain" to include only actions seeking injunctive relief or to encompass instead all suitsequitable and legal-that might "restrain" or impair state or local efforts to assess and collect taxes is an unresolved question. ${ }^{42}$ The

39 Bland v. McHann, 463 F.2d 21, 26 n.21 (5th Cir. 1972) (relying on Perez v. Ledesma, 401 U.S. 82, 128 n.17 (1971) (Brennan, J., concurring in part, dissenting in part)), cert. denied, 410 U.S. 966 (1973); see Tramel v. Schrader, 505 F.2d 1310, 1316 (5th Cir. 1975); Kistner v. Milliken, 432 F. Supp. 1001 (E.D. Mich. 1977); Cornelius v. Benevolent Protective Order of the Elks, 382 F. Supp. 1182, 1193-94 n.15 (D. Conn. 1974) (three-judge court); Horn v. O'Cheskey, 378 F. Supp. 1280, 1283 (D.N.M. 1974).

10 See Harvard Note, supra note 3 , at 782-85.

"See, e.g., Grosjean v. American Press Co., 297 U.S. 233 (1936); City Bank Co. v. Schnader, 291 U.S. 24 (1934); Gully v. Interstate Natural Gas Co., 82 F.2d 145 (5th Cir.), cert. denied, 298 U.S. 688 (1936). But see Matthews v. Rodgers, 284 U.S. 521 (1932); Henrietta Mills v. Rutherford County, 281 U.S. 121 (1930).

${ }^{42}$ Compare Fulton Mkt. Cold Storage Co. v. Cullerton, 582 F.2d 1071 (7th Cir. 1978), 
discussions in the legislative history refer explicitly only to injunctive actions. ${ }^{43}$ The absence of any reference to declaratory judgment or damage actions, however, may be attributed to the absence of such suits in the case law at the time of enactment of the Tax Injunction Act." The federal court practice of that era did not demonstrate the potential of such suits for contesting the validity of state or local taxes prior to payment. ${ }^{45}$ Declaratory judgments were available, but few people were familiar with them; damage suits under section $1983^{46}$ or related civil rights statutes ${ }^{47}$ were not brought because of the restrictive judicial constructions of those statutes. ${ }^{48}$

It seems likely that the legislators believed they were barring all suits that might be brought against taxing officials or a taxing body to contest the validity of a tax prior to its assessment and collection..$^{48}$ The House Report ${ }^{50}$ on the legislation was entitled "Suits Relating to Collection of State Taxes," suggesting that the House Committee on the Judiciary envisioned the Act as removing all actions interfering with collection efforts, although the Committee was probably laboring under the misconception that injunctions constituted the entire universe of such suits. The legislative history ${ }^{51}$

cert. denied, 99 S. Ct. 1033 (1979), Baker v. Strode, 348 F. Supp. 1257 (W.D. Kan. 1972) (three-judge court), Central Steel \& Wire Co. v. City of Detroit, 99 F. Supp. 639, aff'd on rehearing, 101 F. Supp. 470 (E.D. Mich. 1951), and Morrison-Knudsen Co. v. State Bd. of Equalization, 35 F. Supp. 553 (D. Wyo. 1940) with Bland v. McHann, 463 F.2d 21 (5th Cir. 1972), cert. denied, 410 U.S. 966 (1973), Advertiser Co. v. Wallace, 446 F. Supp. 677 (M.D. Ala. 1978), Evangelical Catholic Communion, Inc. v. Thomas, 373 F. Supp. 1342 (D. Vt. 1973), aff'd mem., 493 F.2d 1397 (2d Cir. 1974), and Collier Advertising Serv., Inc. v. City of New York, 32 F. Supp. 870 (S.D.N.Y. 1940). See also Harvard Note, supra note 3; Note, Federal Declaratory Judgments on the Validity of State Taxes, 50 YaLE L.J. 927 (1941).

${ }^{13}$ See H.R. REP. No. 1503, 75th Cong., 1st Sess. (1937); S. ReP. No. 1035, 75th Cong., 1st Sess. (1937); 81 Cong. Rec. 1415, 1415-17 (1937) (remarks of Sen. Bone).

"See Note, Federal Declaratory Judgments on the Validity of State Taxes, supra note 42, at 929-30. Only one reported federal case prior to the Act of 1937 involved a request for a declaration of the validity of the state tax. Id. at 930 n.14. See Gully v. Interstate Natural Gas Co., 82 F.2d 145 (5th Cir.), cert. denied, 298 U.S. 688 (1936).

is See Note, Federal Declaratory Judgments on the Validity of State Taxes, supra note 42 , at $929-30$.

4 42 U.S.C. \& 1983 (1976).

47 Id. $\$ \S 1981$ ("All persons . . . shall be subject to like . . . taxes."), 1985(c) (proscribes conspiracies to deprive persons of equal protection of the laws).

${ }_{48}$ Most importantly, section 1983 was dormant until the Supreme Court's 1961 decision in Monroe v. Pape, 365 U.S. 167 (1965). See Developments, supra note 7, at 1135-36. Only with the Supreme Court's recent decision in Monell v. Department of Social Servs., 436 U.S. 658, 690-91 (1978), did municipalities become liable for damages under section 1983.

13 See E. Borchard, Declaratory Judgments 828 (2d ed. 1941).

${ }^{50}$ H.R. REP. No. 1503, 75th Cong., 1st Sess. (1937).

${ }^{51}$ See, e.g., H.R. REP. No. 1194, 73d Cong., 2d Sess. (1934); S. REP. No. 125, 73d Cong., 1st Sess. (1934); Jurisdiction of District Courts over Suits Relating to Orders of State Administrative Boards: Hearings on S. 752 Before the House Comm. on the Judiciary, 73d Cong., 
of the Johnson Act ${ }^{52}$-the Act after which the Act of 1937 was modeled and which bars "suits to enjoin, suspend or restrain" state rate orders-reflects, in large part, the same concerns that motivated enactment of the Tax Injunction Act. ${ }^{33}$ That legislative history similarly speaks of withdrawing "completely from the district courts of the United States all jurisdiction in suits relating to orders of State administrative boards or commissions affecting rates chargeable by public utilities," ${ }^{44}$ not just foreclosing jurisdiction with respect to injunctive actions.

The legislative history of the Tax Injunction Act does not, however, demonstrate a congressional intention to remove from the federal courts all suits involving state or local tax administration, but only those that permitted the taxpayer to adjudicate the lawfulness of a levy prior to payment. The Senate Report suggests that statelaw refund suits would not be subjected to the jurisdictional bar of the Act. ${ }^{55} \mathrm{~A}$ congressional legal brief on the legislation reproduced in the House Report ${ }^{58}$ stated in part:

[I]f the refund action is permitted by State legislation or rules of decision against counties or county officers, and the money refunded has not yet reached the State exchequer, such actions, if maintainable in the State courts, could likewise be pursued in the Federal courts if the requisite elements of Federal jurisdiction existèd. ${ }^{57}$

Thus, Congress sought federal noninterference with the assessment and collection of state and local taxes, but apparently did not seek

2d Sess. (1934); Limiting Jurisdiction of Federal Courts: Hearing on S. 752 Before a Subcomm. of the Senate Comm. on the Judiciary, 73d Cong., 1st Sess. (1933).

${ }^{52} \mathrm{Ch} .283$, 48 Stat. 775 (1934) (current version at 28 U.S.C. $\$ 1342$ (1976)). The current version provides in part:

The district courts shall not enjoin, suspend or restrain the operation of, or compliance with, any order affecting rates chargeable by a public utility and made by a State administrative agency or a rate-making body of a State political subdivision, where:

(1) Jurisdiction is based solely on diversity of citizenship or repugnance of the order to the Federal Constitution; and,

(4) A plain, speedy and efficient remedy may be had in the courts of such State. s See S. Rep. No. 1035, 75th Cong., 1st Sess. 2 (1937); 81 Cong. REc. 1416 (1937) (remarks of Sen. Bone).

st H.R. REP. No. 1194, 73d Cong., 2d Sess. 2 (1934).

${ }^{55}$ See S. REP. No. 1035, 75th Cong., 1st Sess. 1-2 (1937), quoted in H.R. REP. No. 1503, 75th Cong., 1st Sess. 1-2 (1937).

${ }^{56}$ H.R. Rep. No. 1503, 75th Cong., 1st Sess. 2-4 (1937).

57 Id. at 3 . 
to withdraw the power of the federal courts to entertain suits challenging a levy once the taxes had been collected. ${ }^{58}$

\section{Judicial Development of Section 1341: Actions for InJunctive aNd Declaratory ReLief}

The judicial application of section 1341 to actions seeking injunctive or declaratory relief has been varied. Although the courts have conscientiously wielded the jurisdictional bar against injunctions, ${ }^{59}$ they have applied the Act to declaratory judgments much less consistently. When confronted with prayers for declaratory relief from state or local taxes, the federal courts have instead frequently applied the doctrine of judicial abstention. Despite the facial disparity between the courts' treatment of these two types of equitable actions, the rationales underlying the decisions reflect a common, consistent policy, which provides a basis for defining the contours of section 1341's applicability to actions for monetary judgment.

\section{A. Injunctions}

Since the phrase "enjoin, suspend or restrain" on its face encompasses injunctions against state or local tax collection, the federal courts have had relatively little difficulty applying section 1341 to injunctive actions. Not all tax-related injunctions directly enjoin the tax itself, however: an injunction may indirectly or incidentally restrain the collection of a tax. Several of the cases applying section 1341 have determined the applicability of the section by examining the extent of the restraint likely to result from the requested injunction. ${ }^{60}$ If the injunction would interfere with the enforcement mecha-

ss Cf. Act of Mar. 2, 1867, ch. 169, § 10, 14 Stat. 475 (current version at 26 U.S.C. $\S$ 7421(a) (1976)) (providing in part that "no suit for the purpose of restraining the assessment or collection of any [federal] tax shall be maintained in any court"). The Supreme Court found the "manifest purpose" of the provision was "to permit the United States to assess and collect taxes alleged to be due without judicial intervention, and to require that the legal right to a disputed sum be determined in a suit for a refund." Enochs v. Williams Packing \& Navigation Co., 370 U.S. 1, 7 (1962). In a footnote, the Court quoted from the Senate Report on the bill that became the Act of 1937, S. Rep. No. 1035, 75th Cong., 1st Sess. 2 (1937). 370 U.S. at 7 n.6.

3) See, e.g., Tully v. Griffin, Inc., 429 U.S. 68 (1976); 28 East Jackson Enterprises, Inc. v. Cullerton, 523 F.2d 439 (7th Cir. 1975), cert. denied, 423 U.S. 1073 (1976); City of Orange v. Levingston Shipbuilding Co., 258 F.2d 240 (5th Cir. 1958); Michael v. Cockerell, 161 F.2d 163 (4th Cir. 1947); Baker v. Atchison, T. \& S.F. Ry., 106 F.2d 525 (10th Cir.), cert. denied, 308 U.S. 620 (1939); Hammonds v. City of Corpus Christi, 226 F. Supp. 456 (S.D. Tex. 1964), aff'd, 343 F.2d 162 (5th Cir.), cert. denied, 382 U.S. 837 (1965).

co See, e.g., Lawrence Print Works v. Lynch, 146 F.2d 996 (1st Cir. 1945) (grant of specific 
nism of the tax, ${ }^{61}$ the courts have found such relief "within the spirit and purpose of the statute." 62

The courts have also applied a functional approach to the Act in holding that section 1341 does not bar all federal injunctive interference with state or local taxation, but only that which actually "restrains" collection of the tax. ${ }^{63}$ In Hargrave $v$. McKinney, ${ }^{64}$ for example, a plaintiff attacked as unconstitutional a Florida statute that cut off state funds to any county that imposed a property tax for educational purposes over a certain limit. The majority of a divided Fifth Circuit panel characterized the action as one seeking to order the collection and distribution of county taxes. ${ }^{65}$ The majority, citing the legislative history of the Tax Injunction Act, found the suit to be outside of the jurisdictional bar of section $1341 .{ }^{66}$ The court reasoned that since the plaintiff sought to compel the collection of the tax, and not to "enjoin, suspend or restrain" its collection, the court would not frustrate the statutory policy of "protect[ing] the integrity of the state treasury" by entertaining the action. ${ }^{67}$

performance of a contract between taxpayer-plaintiff and city to abate certain taxes precluded by the Act of 1937); Sears, Roebuck \& Co. v. Roddewig, 24 F. Supp. 321 (S.D. Iowa 1938) (court held that Act of 1937 barred a request for an injunction to prevent the state's cancellation of plaintiff's sales permit). The Lawrence Print Works decision is discussed in Harvard Note, supra note 3 , at 788-89.

of In Sears, Roebuck \& Co. v. Roddewig, 24 F. Supp. 321 (S.D. Iowa 1938), the district court reasoned that cancellation of a sales permit constituted a penalty for the taxpayer's failure to collect and remit taxes. Id. at 324 . But see Wells v. Malloy, 510 F.2d 74 (2d Cir. 1975). The court in Wells construed the term "collection" in section 1341 narrowly. The plaintiff, an indigent, sought an injunction to prevent the enforcement of a section of the Vermont Motor Vehicle Purchase and Use Tax statute, under which the state had revoked his license for failure to pay the tax. The Second Circuit panel held the action outside the bar of section 1341 because the term "collection" in the statute was meant to include "methods similar to assessment and levy . . . that would produce money or other property directly, rather than indirectly through a more general use of coercive power." Id. at 77 (citations omitted).

${ }^{22}$ Lawrence Print Works v. Lynch, 146 F.2d 996, $997-98$ (1st Cir. 1945); cf. Kohn v. Central Distrib. Co., 306 U.S. 531 (1939) (Act of 1937 barred taxpayer's suit in federal court to enjoin state-court proceedings by which the state was seeking to collect taxes from him) (alternative holding).

os See generally Harvard Note, supra note 3, át 786-89; Note, Federal Declaratory Judgments on the Validity of State Taxes, supra note 42, at 931-34.

of 413 F.2d 320 (5th Cir. 1969).

is Id. at 326.

ss Id. at 325-26.

67 Id. at 326. See Cornelius v. Benevolent Protective Order of the Elks, 382 F. Supp. 1182 (D. Conn. 1974) (three-judge court). The plaintiff in Cornelius sought, among other things, to enjoin state officials from continuing the defendant organizations' exemption from the state business corporation tax and to collect back taxes from the defendants that would have been owed but for the exemption. The court held that section 1341 did not apply, since it was aimed at "judgments inhibiting rather than compelling the collection of taxes." Id. at 


\section{B. Declaratory Judgments}

Shortly after the adoption of the Act of 1937, the courts faced the question whether the statutory provision comprehends declaratory judgments. Two early district court decisions reached inconsistent results. ${ }^{8}$ In 1943 , six years after the enactment of the jurisdictional bar, the issue came before the Supreme Court in the case of Great Lakes Dredge \& Dock Co. v. Huffman. ${ }^{60}$

The plaintiffs in Great Lakes had unsuccessfully brought an action in federal district court for a declaration that the Louisiana Unemployment Insurance Tax was unconstitutional as applied to the plaintiffs and their employees. ${ }^{70}$ The Supreme Court, addressing neither the constitutionality of the state levy nor the applicability of the Tax Injunction Act, held that the district court should never have reached the merits: the court should have exercised its equitable power to abstain from entertaining the suit. The Court stated

1193 (footnote omitted). The court, citing the legislative history of the Act, asserted that Congress did not intend to bar the federal courts from hearing suits that would swell the state coffers. Id. at 1193 n.15; cf. Griffin v. County School Bd., 377 U.S. 218, 233 (1964) (court may require local authorities to exercise tax power to implement school desegregation) (dictum).

"s In Morrison-Knudsen Co. v. State Bd. of Equalization, 35 F. Supp. 553 (D. Wyo. 1940), the court held that the Act posed no barrier to the plaintiff's request for declaratory relief against state taxes. In reaching this conclusion, the court noted that the Declaratory Judgments Act of 1934, ch. 512, 48 Stat. 955, as amended by Act of Aug. 30, 1935, ch. 829, $\$ 405$, 49 Stat. 1027 (current version of Declaratory Judgments Act at 28 U.S.C. $\$ \S 2201-2202$ (1976)), prohibited declaratory relief against federal taxes, but was silent with respect to declaratory judgments against state taxes. In Collier Advertising Serv., Inc. v. City of New York, 32 F. Supp. 870 (S.D.N.Y. 1940), however, the district court held that declaratory relief was within the ambit of the Act of 1937. The court observed that the Act does not distinguish between causes of action or forms of relief. "It would be disingenuous," the court said, "to deny that a declaration of the plaintiff"s claimed rights in this action would secure any other result than to enjoin, suspend and restrain." Id. at 872 . For a discussion of these cases, see E. Borchard, supra note 49, at 828; Note, Federal Declaratory Judgments on the Validity of State Taxes, supra note 42. With respect to the Collier case, Professor Borchard wrote:

District Judge Clancy was probably correct in refusing under the . . . Act [of 1937] to take jurisdiction of a federal suit for a declaratory judgment to hold invalid the $2 \%$ New York City sales tax as applied to the purchase of 12 cents or less . . . Judge Clancy considered . . . that whereas the .. . Act prohibited him only "to enjoin, suspend or restrain," nevertheless adjudication in the form of a declaratory judgment amounted to the same thing. In so holding, the court was apparently correct, for the . . . Act was designed to prevent federal assumption of jurisdiction to adjudiate and not merely the issuance of an injunction.

E. Borchard, supra note 49 , at 828 (footnote omitted). For a decision similar to Collier and relying on the analysis of Collier and Professor Borchard, see West Publishing Co. v. McColgan, 138 F.2d 320 (9th Cir. 1943).

" 319 U.S. 293 (1943).

7 The district court found the tax constitutional, 43 F. Supp. 981 (E.D. La. 1942), and the court of appeals affirmed, 134 F.2d 213 (5th Cir. 1943). 
as a general principle that federal courts should decline to exercise jurisdiction over actions seeking declarations of the unlawfulness of state or local taxes when state remedies are adequate. ${ }^{71}$ In so doing, the Court skirted the issue of the applicability of the Tax Injunction Act. Instead, Chief Justice Stone relied on the Court's earlier decision in Matthews $v$. Rodgers" for the notion that "sound discretion" requires federal courts to refrain from prospective interference with" the processes of state and local taxation. The Great Lakes Court quoted the following Matthews dictum:

The scrupulous regard for the rightful independence of state governments which should at all times actuate the federal courts, and a proper reluctance to interfere by injunction with their fiscal operations, require that such relief should be denied in every case where the asserted federal right may be preserved without it. ${ }^{73}$

The court reasoned that declaratory judgments, because they are equitable causes of action, should be subject to the Matthews abstention doctrine. ${ }^{74}$

Despite the failure of the Great Lakes Court to reach the statutory question, ${ }^{75}$ and its reliance instead on an abstention doctrine, the decision is instructive. The Court isolated what it thought motivated Congress to enact the jurisdictional bar of section 1341: a concern about the impact of federal interference on state revenue collection. ${ }^{76}$ The Court, in declining to decide whether the Tax Injunction Act barred such actions, noted that the Act refers only to suits "to enjoin, suspend, or restrain the assessment, levy, or collection of any tax" imposed pursuant to state statute. Although the declaratory-judgment procedure does not have the same coercive effect as an injunction, the Court said that it "may in every practi-

11319 U.S. at 298.

72284 U.S. 521 (1932).

${ }^{23} 319$ U.S. at 298 (quoting Matthews v. Rodgers, 284 U.S. 521, 525 (1932)).

7319 U.S. at 300. See also F. JAMEs \& G. HAzARD, Civit, Procedure § 1.10, at 30-31 (2d ed. 1977).

75 See 319 U.S. at 299.

76 Interference with state internal economy and administration is inseparable from assaults in the federal courts on the validity of state taxation, and necessarily attends injunctions, interlocutory or final, restraining collection of state taxes. These are the considerations of moment which have persuaded federal courts of equity to deny relief to the taxpayer-especially when the state, acting within its constitutional authority, has set up its own adequate procedure for securing to the taxpayer the recovery of an illegally exacted tax.

Id. at 298 . 
cal sense operate to suspend collection of the state taxes until the litigation is ended."'77

The Great Lakes abstention doctrine spared later courts the need to consider the applicability of the Act to declaratory-judgment actions. ${ }^{78}$ Despite the availability of that doctrine, however, many courts have held that such suits fall within the jurisdictional bar of section 1341. Some courts have interpreted the Great Lakes decision as holding that the jurisdictional bar-rather than an abstention doctrine-applies to declaratory judgments. ${ }^{79}$ Most of the other courts invoking section 1341 have merely concluded, without analysis or discussion, that the statute applies. ${ }^{80}$ The tendency among the lower courts to adopt this broader view of section $1341^{81}$ can perhaps be explained by the language of the Court's opinion in Great Lakes. The Court's statement that the Act of 1937 "was predicated upon the desirability of freeing, from interference by the federal courts, state procedures which authorize litigation challenging a tax only after the tax has been paid"82 makes it difficult to adopt the narrow view that the Act was directed only at injunctive actions, rather than at all actions that have a disruptive impact on state tax collection.

\section{Actions For Monetary Judgment}

Three types of monetary-judgment actions related to state taxes have typically been brought in federal court: state-law refund suits, ${ }^{83}$ section 1983 suits seeking as damages the amount of taxes

"Id. at 299. The Court's conclusion was sound: the potential impact of a federal declaratory judgment is nearly as great as that of an injunction. See E. BorCHARD, supra note 49, at 896.

${ }^{78}$ Cf. Klotz v. Consolidated Edison Co., 386 F. Supp. 577, 585 n.5 (S.D.N.Y. 1974) ("It is likely that it is only the existence of the doctrine of Great Lakes Dredge \& Dock Co. v. Huffman . . . which has prevented a decision by the Supreme Court on whether a declaratory judgment is encompassed by [section 1341].").

7 E.g., ALCOA v. Department of Treasury, 522 F.2d 1120, 1122-23 (6th Cir. 1975); Wyandotte Chems. Corp. v. City of Wyandotte, 321 F.2d 927, 929 (6th Cir. 1963); Kimmey v. H.A. Berkheimer, Inc., 376 F. Supp. 49, 53 (E.D. Pa. 1974), aff'd mem., 511 F.2d 1394 (3d Cir. 1975); Northern Natural Gas Co. v. Wilson, 340 F. Supp. 1126, 1128-29 (D. Kan. 1971) (per curiam) (three-judge court); Zenith Dredge Co. v. Corning, 231 F. Supp. 584, 587 (W.D. Wis. 1964).

so E.g., Charles R. Shepherd, Inc. v. Monaghan, 256 F.2d 882 (5th Cir. 1958); Green v. Klinkofe, 422 F. Supp. 1021, 1024-25 (N.D. Ind. 1976); Klotz v. Consolidated Edison Co., 386 F. Supp. 577, 585 (S.D.N.Y. 1974) (dictum); Amex-Champlain Corp. v. Gallman, 422 F. Supp. 292, 293 (N.D.N.Y. 1973) (three-judge court); Reiling v. Lacy, 93 F. Supp. 462, 468-70 (D. Md. 1950) (three-judge court), appeal dismissed per curiam, 341 U.S. 901 (1950).

81 See 17 C. Wright, A. Muler \& E. CoOper, supra note 2, § 4237, at 418.

32319 U.S. at 301.

ss See, e.g., cases cited at note 12 supra. 
paid, ${ }^{84}$ and section 1983 actions seeking damages for some injury other than the actual payment of taxes..$^{85}$ Judicial application of section 1341 to these three forms of monetary-judgment action has been inconsistent, largely because of the different postures in which the suits arise. As a result, the decisions only vaguely delineate the limits of section 1341's applicability.

\section{A. Refund Actions}

The courts have sometimes failed to distinguish state-law refund suits from damage actions that seek as part or all of the requested relief the return of taxes paid. ${ }^{86}$ Refund-type damage actions brought against a public official or a political subdivision of the state must, however, be distinguished from state-law refund suits in several respects. First, state-law remedies entitle taxpayers to the return of taxes that were unlawfully exacted; damage actions assert that the taxpayer has suffered injury as a result of an unlawful levy and that he should be compensated, in part, through return of the amount of taxes paid. Second, the state-law refund suit results in disgorgement of funds from the taxing body itself; damages awarded in a section 1983 refund-like suit may be assessed either against the taxing official ${ }^{87}$ or, in some cases, against the governmental body. ${ }^{88}$ The procedural postures differ significantly as well. State-law suits may be brought in federal court-save for any bar section 1341 might present-only under diversity jurisdiction or, if they are under the same operative facts as a federal claim, under the court's pendent jurisdiction. ${ }^{89}$ Damage actions, however, are usually predicated on section 1983 and thus can be brought under the jurisdictional grant of section 1343(3) of Title 28 of the United States Code. ${ }^{90}$ Finally, diversity suits predicated on state law, unlike damage suits under federal law, generally require the plaintiff to exhaust his state administrative remedies. ${ }^{91}$

8t See, e.g., Kelly v. Springett, 527 F.2d 1090 (9th Cir. 1975); Bland v. McHann, 463 F.2d 21 (5th Cir. 1972), cert. denied, 410 U.S. 966 (1973).

8s See, e.g., Ludwin v. City of Cambridge, 592 F.2d 606 (1st Cir. 1979); Fulton Mkt. Cold Storage Co. v. Cullerton, 582 F.2d 1071 (7th Cir. 1978), cert. denied, 99 S. Ct. 1033 (1979); Advertiser Co. v. Wallace, 446 F. Supp. 677 (M.D. Ala. 1978).

s6 See, e.g., Kelly v. Springett, 527 F.2d 1090 (9th Cir. 1975); Bland v. McHann, 463 F.2d 21 (5th Cir. 1972), cert. denied, 410 U.S. 966 (1973); Evangelical Catholic Communion, Inc. v. Thomas, 373 F. Supp. 1342 (D. Vt. 1973), aff'd mem., 493 F.2d 1397 (2d Cir. 1974).

${ }^{87}$ See note 7 supra.

See note 8 supra.

se See UMW v. Gibbs, 383 U.S. 715 (1966).

9028 U.S.C. § 1343(3) (1976).

of State statutes generally provide that suits may be brought only on such terms. See, 
The courts have not always been clear in explaining the relationship between section 1341 and these two forms of refund action. The legislative history of section 1341 demonstrates that Congress did not envision application of the statute to state-law refund suits. ${ }^{92}$ Only in a few instances have such suits been brought in federal court, ${ }^{23}$ but the courts have consistently found that section 1341 was no bar to the suits. ${ }^{94}$ These decisions have not relied on the legislative history, however, and have failed to provide any reasons for concluding that the statute does not apply. Moreover, although state-law refund suits are analytically distinguishable from refundtype damage suits, several decisions have cited the state-law cases for the proposition that section 1341 is inapplicable to refund-type damage actions..$^{95}$

The leading case cited by most courts as holding that section 1341 does apply to refund-type damage actions is the Fifth Circuit's decision in Bland v. McHann..$^{96}$ In Bland, the taxpayers sued municipal officials for an injunction and damages under section 1983. They sought damages in the form of taxes already paid, and an injunction to prevent the officials from continuing their allegedly unconstitutional tax assessments. The court addressed two questions: whether section 1341 governed actions brought under section 1983 and, if so, whether it applied to a refund action. The court quickly rejected the plaintiffs' claim that section 1983 actions were immune from section $1341^{77}$ and focused its attention on the status of the refund claim under section 1341. The court initially observed that the statutory language, on its face, offers a "compelling" argument that section 1341 does not preclude refund actions. But the court noted that it had "already held $\S 1341$ applicable to bar relief under a complaint which sought a refund as well as anticipatory relief." ${ }^{\prime \prime 8}$ Since the earlier holding did not ex-

e.g., Ark. Stat. AnN. $§ 84-2038$ (1960); Cal. Rev. \& Tax. Code $\$ 5142$ (West Supp. 1979); Kan. Stat. ANN. $\$ 79-2005$ (1977). These statutes control in diversity suits pursuant to the Rules of Decision Act, 28 U.S.C. $\S 1652$ (1976).

12 See text and notes at notes 55-57 supra.

3 Among the cases reported are those cited at note 12 supra. See also Southland Mall, Inc. v. Garner, 293 F. Supp. 1370 (W.D. Tenn. 1968), aff'd, 455 F.2d 887 (6th Cir. 1972).

" See cases cited at note 12 supra.

is E.g., Bland v. McHann, 463 F.2d 21, 25 \& n.13 (5th Cir. 1972), cert. denied, 410 U.S. 966 (1973); Evangelical Catholic Communion, Inc. v. Thomas, 373 F. Supp. 1342, 1344 (D. Vt. 1973), aff'd mem., 493 F.2d 1397 (2d Cir. 1974).

* 463 F.2d 21 (5th Cir. 1972), cert. denied, 410 U.S. 966 (1973).

${ }^{77}$ Id. at 25. See Lynch v. Household Fin. Corp., 405 U.S. 538, 542 n.6 (1972) (dictum); American Commuters Ass'n v. Levitt, 405 F.2d 1148, 1151 (2d Cir. 1969); text and notes at notes 142-143 infra.

98 463 F.2d at 25 (citing Kiker v. Hefner, 409 F.2d 1067 (5th Cir. 1969)). 
plain why the refund action was barred, the court did not rely on it exclusively. "[E]ven apart from the statute," the court said, "sound judicial policy precludes consideration of the action . . . "998

Turning to the Supreme Court's decision in First National Bank v. Board of County Commissioners, ${ }^{100}$ the Fifth Circuit reasoned that that case "clearly would leave taxpayers to their state remedy, if it is plain, adequate and complete." 101 But the court's reliance on that pre-section 1341 decision is puzzling. The plaintiff in First National Bank had sued in federal district court for a refund of Colorado property taxes that allegedly were unconstitutionally imposed; the action was, however, a state-law refund suit, and not one for damages. The Supreme Court, affirming the district court's dismissal of the action, held that the plaintiff's failure to exhaust the administrative remedies provided by state statute constituted grounds for dismissal. ${ }^{102}$ The argument that First National Bank "alone would seem to effectively preclude the action here for a refund if the state remedy is adequate"103 seems unfounded. The First National Bank decision dictates exhaustion of administrative remedies, not exhaustion of all adequate state legal remedies, as Bland held. ${ }^{104}$

The court did not, however, rely exclusively on First National

9963 F.2d at 26.

${ }^{100} 264$ U.S. 450 (1924).

101463 F.2d at 27.

102 Under the doctrine of exhaustion of administrative remedies, one cannot seek judicial relief until all available administrative remedies have been exhausted. See Myers v. Bethlehem Shipbuilding Corp., 303 U.S. 41, 50-51 (1938). See generally Comment, Exhaustion of State Administrative Remedies in Section 1983 Cases, 41 U. CH. L. REv. 537, 538-40 (1974). Indeed, the Court in Myers even cited to First Nat'l Bank v. Board of County Comm'rs, 264 U.S. 450 (1924), as support for an exhaustion doctrine. 303 U.S. at 51 n.9. The Supreme Court has noted that the exhaustion doctrine "is of especial force when resort is had to the federal courts to restrain the action of state officers." Natural Gas Pipeline Co. v. Slattery, 302 U.S. 300,311 (1937). Yet the doctrine has never been read as requiring the exhaustion of state judicial-rather than administrative-remedies. See Monroe v. Pape, 365 U.S. 167, 183 (1961); Developments, supra note 7, at 1264. In four Supreme Court cases after Monroe, the Court held that no exhaustion of state administrative remedies was required in suits brought under section 1983. Houghton v. Shafer, 392 U.S. 639 (1968); King v. Smith, 392 U.S. 309 (1968); Damico v. California, 389 U.S. 416 (1967); McNeese v. Board of Educ., 373 U.S. 668 (1963). But see Eisen v. Eastman, 421 F.2d 560 (2d Cir. 1969) (Friendly, J.), cert. denied, 400 U.S. 841 (1970). See also Developments, supra note 7, at 1264-74; Comment, supra, at $542-47$. For an argument that an exhaustion-of-administrative-remedies requirement should be applied to refund-type damage actions, see Note, Limiting Federal Jurisdiction in Section 1983 Damage Actions Against Tax Officials, 74 Nw. U.L. Rev. 284 (1979).

${ }^{103} 463$ F.2d at 26.

tas Thus, section 1341 is more than a codification of the exhaustion doctrine in the context of state taxation, see note 102 supra; it establishes an additional requirement of exhaustion of legal remedies. 
Bank for its conclusion that "sound judicial policy precludes consideration of the action." The principle of judicial restraint in state tax cases expressed in Matthews $v$. Rodgers, and given added force by the enactment of section 1341 and the Supreme Court's decision in Great Lakes, also influenced the court. ${ }^{105}$ Since refund actions are "an integral part of state tax administration," 106 the court found that principle persuasive in requiring it to withhold relief. Especially when, as in Bland, the plaintiffs joined their refund claim with a claim for anticipatory relief barred explicitly by section 1341, the court chose to send the taxpayers to state court on both claims, rather than "bifurcate the state remedy." 107

Bland is an interesting case. Although the court characterized the monetary claim in the action as a refund claim, it applied section 1341 with no apparent regard for Congress's belief that statelaw refund actions were to be outside the scope of the section. ${ }^{\text {us }}$ Bland also applied section 1341 to a legal action, thus apparently rejecting any notion that the section governs only equitable relief. But the rejection was only provisional. The court seemed to tie its application of the section to the particular situation in which a plaintiff brings a refund claim simultaneously with a claim for injunctive relief obviously barred by section 1341 . Moreover, the reasoning of the court was similar to that of the Supreme Court in Great Lakes: it relied heavily upon the pre-section 1341 judicial abstention doctrine and treated the statute only tangentially. Thus, when the court concluded that " $\$ 1341$ is applicable and that the action for a refund is precluded where the state remedy is adequate,"100 its actual holding was ambiguous.

Despite its patent ambiguity and the court's heavy emphasis on the ancillary claim for injunctive relief, Bland has come to be accepted as an application of section 1341 to refund-type damage actions. ${ }^{110}$ The subsequent case law contains little analysis of the propriety of so extending the section, and the contrasting treatment of state-law refund actions is continually given short shrift. As will be seen, a more reasoned application of section 1341 is possible.

tas 463 F.2d at $26-27$.

104 Id. at 27.

${ }^{107} \mathrm{Id}$.

1as See text and notes at notes 55-57 supra.

100463 F.2d at 28.

"10 See, e.g., Kelly v. Springett, 527 F.2d 1090, 1094 (9th Cir. 1975); Advertiser Co. v. Wallace, 446 F. Supp. 677, 679 (M.D. Ala. 1978); Evangelical Catholic Communion, Inc. v. Thomas, 373 F. Supp. 1342, 1344 (D. Vt. 1973), aff'd mem., 493 F.2d 1397 (2d Cir. 1974). 


\section{B. Non-Refund Damage Actions}

When damages sought by a taxpayer-plaintiff do not merely represent reimbursement of taxes paid, the courts have reached inconsistent results. ${ }^{111}$ Non-refund damage actions, although not within the literal scope of the statute, may implicate the policy underlying section 1341 because of their impact on state or local tax collection. The result of such an action is not an injunction against the collection of a disputed tax, but the outcome of the suit usually turns on a determination of the lawfulness of the tax. ${ }^{12}$ In many instances, this type of action seeks damages for injury caused even before the taxpayer has paid the allegedly unlawful tax. ${ }^{113}$

In Evangelical Catholic Communion, Inc. v. Thomas, ${ }^{114}$ a Vermont district court found section 1341 applicable to a non-refundtype claim for damages. The plaintiffs contended that property owned by Evangelical Catholic Communion, Inc., one of the plaintiffs, as well as property used by the organization but owned by some of its members, should be exempt from the local property tax of Newbury, Vermont, because the properties were used for charitable purposes. Basing their action on section 1983, the plaintiffs sought an injunction preventing the further assessment of taxes on the property, refund-type damages, and additional damages of $\$ 150,000$. The court invoked section 1341 and barred all relief. ${ }^{15}$ The court, relying on Bland $v$. McHann, ${ }^{116}$ found that the refund element of the damages should be treated no differently than an injunction. ${ }^{117}$ Addressing the claim for additional damages, the court noted:

[T] a determination by this court that the taxation of their Newbury property was effected in violation of their constitutional rights. If we were to make such a determination, we would, in effect, be issuing a declaratory judgment regarding the consti-

11 Compare, e.g., Advertiser Co. v. Wallace, 446 F. Supp. 677 (M.D. Ala. 1978) with Fulton Mkt. Cold Storage Co. v. Cullerton, 582 F.2d 1071 (7th Cir. 1978), cert. denied, 99 S. Ct. 1033 (1979).

${ }^{112}$ See Evangelical Catholic Communion, Inc. v. Thomas, 373 F. Supp. 1342, 1344 (D. Vt. 1973), aff'd mem., 493 F.2d 1397 (2d Cir. 1974).

113 The alleged injury will usually be related to attempts to collect the taxes: for example, attorneys' fees and costs incurred in resisting imposition of the tax, or a cloud on the title of real property resulting from failure to pay taxes.

11 373 F. Supp. 1342 (D. Vt. 1973), aff'd mem., 493 F.2d 1397 (2d Cir. 1974).

IIs Id. at 1343.44.

116463 F.2d 21 (5th Cir. 1972), cert. denied, 410 U.S. 966 (1973).

11373 F. Supp. at 1344. 
tutionality of the tax levied on the plaintiffs. As the court is prohibited from issuing such a declaratory judgment [by section 1341], . . . the court is also precluded as a matter of law from adjudicating the plaintiffs' damages claims. ${ }^{118}$

The court, like the court in Bland, implicitly rejected any distinction for purposes of section 1341 based on the form-equitable or legal-of the action. It seemed to move beyond Bland, however, and embrace a much broader noninterference approach to section 1341: the bar applies to suits brought in federal court that would require judicial determination-explicit or implicit-of the validity of a state or local tax. Whether the damages sought are equivalent to a refund is inconsequential under the Evangelical Catholic Communion standard. Although the taxpayer in that case had paid the allegedly unlawful tax, the logic of the decision would apply as well to an action challenging taxes not yet paid, since in such a case the court would be required to adjudicate the constitutionality of the tax.

In Advertiser Co. v. Wallace, ${ }^{119}$ an Alabama district court addressed the applicability of section 1341 to a prepayment suit for injuries sustained as a result of the attempted collection of the disputed taxes. Although the taxes had not yet been paid, the plaintiff sought compensatory and punitive damages for deprivation of its first and fourteenth amendment rights through "arbitrary" assessments. ${ }^{120}$ The district court held that section 1341 barred the plaintiff's section 1983 suit. ${ }^{121}$ In reaching this conclusion, the court reasoned that the rule in refund-type cases should apply to Advertiser's cause of action because of the potential interference of such a damage suit with state tax collection. ${ }^{122}$ The court noted that the plaintiff's suit, especially the request for punitive damages, "is designed to deter collection of the taxes now being assessed by defendants. Particularly since final assessments have not been made, the threat of an adverse monetary judgment may well cause defendants to await the outcome of this action before proceeding any further." ${ }^{23}$

ux Id. See Ludwin v. City of Cambridge, 592 F.2d 606, 610 (1st Cir. 1979) (determining liability of tax officials would require "ascertaining the correctness of the assessment").

'11 446 F. Supp. 677 (M.D. Ala. 1978).

120 The two newspapers owned by the plaintiff had published criticisms of Governor Wallace's administration. The suit alleged that the state officials had arbitrarily imposed sales and lease tax assessments, and were attempting to collect the increased tax assessments to punish the plaintiff for the criticisms. Id. at 678 .

121 Id. at 679.

122 Id. at $679-80$.

123 Id. at 680 . 
In addition, the court noted that entertaining a claim for "punitive and unspecified compensatory damages" would undermine the federal judicial policy of hearing only those cases in which the court can afford "complete relief." 124 In this case, if the plaintiff were forced to pay some of the taxes before final disposition of the case, any refund-type damage claim for such taxes would be barred by Bland's interpretation of section $1341 .^{125}$

Advertiser Co., like Evangelical Catholic Communion, goes well beyond the refund focus of Bland. The court adopted the broadest conceivable impact test for determining the applicability of section 1341: where federal relief might restrain future collection of a state or local tax, section 1341 bars the exercise of federal jurisdiction. The standard is close to that embraced by the court in Evangelical Catholic Communion, which concluded that section 1341 bars federal adjudication of a section 1983 suit that would require a determination of the validity of the imposition of the tax. It is likely that the Evangelical Catholic Communion court would have applied the same test to the suit in Advertiser Co., and thus would have reached the same result as the Alabama court did by applying its "restraining impact" standard. Conversely, the Advertiser $C o$. standard would most likely bar a postpayment damage suit such as that in Evangelical Catholic Communion because the state or local government might be deterred from enforcing its tax before the outcome of the pending action, for fear of incurring further damage suits by other taxpayers.

The Seventh Circuit implicitly rejected the reasoning of the Evangelical Catholic Communion and Advertiser Co. courts in Fulton Market Cold Storage Co. v. Cullerton. ${ }^{126}$ The Seventh Circuit panel held the Tax Injunction Act inapplicable to a section 1983 suit against county and state taxing officials. The taxpayer, Fulton Market, alleged that the defendant county and state officials

${ }^{126}$ Id. The court relied on Mandel v. Hutchinson, 336 F. Supp. 772 (C.D. Cal. 1971), aff'd, 494 F.2d 364 (9th Cir. 1974), which held that section 1341 bars an "ancillary" refund claim along with an injunctive claim. What the Mandel court labeled as a refund claim was presumably a refund-type damage claim brought, along with the injunctive claim, under section 1983. The court used the term "ancillary" not in its jurisdictional sense, but rather to denote the relative insignificance of the monetary claim in relation to the injunctive one. In Bland v. McHann, 463 F.2d 21 (5th Cir. 1972), cert. denied, 410 U.S. 966 (1973), see text and notes at notes 96-110 supra, Judge Gewin also referred to the refund claim as an ancillary one. 463 F.2d at 27. It is arguable that the holdings of Mandel and Bland should be limited to refundtype damage claims that are brought in conjunction with and ancillary to claims for injunctive relief. The reasoning of Mandel especially demands such a reading. $336 \mathrm{~F}$. Supp. at 780 .

125 See text and notes at notes 98-110 supra.

128582 F.2d 1071 (7th Cir. 1978), cert. denied, 99 S. Ct. 1033 (1979). 
had overassessed the value of its property for purposes of a real property tax. Although the taxpayer had obtained refunds under state statutes for all but one of the years in question, ${ }^{127}$ it sought as part of the section 1983 suit compensatory damages of $\$ 60,000$ plus the expenses incurred in seeking the refunds in state court, injuries to the business resulting from the overassessments, and punitive damages. ${ }^{128}$

Judge Sharp's opinion for the court first examined the legislative history of section 1341, reaching the conventional conclusion that the policies underlying the statute were concerned with discrimination between citizens and foreign corporations ${ }^{129}$ and with disruption of state and local taxing processes. ${ }^{130}$ The court then noted that although the legislative history of section 1341 only spoke of injunctions, several courts had extended the jurisdictional bar to declaratory actions because of "the policy considerations and congressional intent of section 1341."131 Concluding that only federal equitable relief was within the ambit of section 1341, the court stated that the statutory language, legislative history, and case law all indicated the "primary evil" the statute was designed to prevent was relief that would disrupt state or local taxing processes. ${ }^{132}$ Moreover, an injunction or declaratory judgment issued by a federal court "would not only undermine and jeopardize a state's ability to collect its revenue but would also seriously damage the delicate balance inherent in our federalistic system of government." 133 The court concluded that a damage suit did not implicate such concerns. Thus, the court found controlling significance in the legal, rather than equitable, nature of the relief sought and permitted the plaintiff's section 1983 damage action despite section 1341 .

The limits of the Fulton Market approach are unclear. Although it isolated two policy considerations underlying section 1341-discrimination and interference with state tax collection-the court concentrated solely on the interference aspect. By excluding damage actions from the scope of section 1341, the Sev-

127 See Reply Brief for Plaintiff/Appellant at 3, 5, 7, Fulton Mkt. Cold Storage Co. v. Cullerton, 582 F.2d 1071 (7th Cir. 1978), cert. denied, 99 S. Ct. 1033 (1979). The court apparently found no significance in the fact that the plaintiff had not paid the taxes for one of the years in question since the opinion does not mention it.

125582 F.2d at 1073.

122 Id. at 1074. See text and notes at notes 27-28 supra.

130582 F.2d at 1075. See text and notes at notes 35-39 supra.

131582 F.2d at 1075.

132 Id. at 1078 .

${ }^{133}$ Id. 
enth Circuit adopted a much narrower approach to the statute than the standards set forth in Bland, Evangelical Catholic Communion, and Advertiser Co. The Fulton Market court's conclusion that the noninterference objective would not be furthered by applying section 1341 to damage actions seems sound when the taxes have already been paid. ${ }^{134}$ In such cases, the state or local government. has the disputed revenues at its disposal, and the federal suit creates no disruption of the continuity of revenue collection. If the taxes have not been paid, however, the soundness of the conclusion is far less certain, since, as Advertiser Co. pointed out, the effect of a judgment in such a case is often indistinguishable from that of a declaratory judgment or an injunction.

The judicial treatment of tax-related damage actions is in a state of flux; the recent flurry of such suits has engendered widely varied judicial responses. The precise rationales of the cases are inconsistent; with the notable exception of Fulton Market, they have generally rejected the narrow view of section 1341 as directed only at equitable actions. The task for the courts is to forge a theoretical and functional approach to section 1341 that may easily and consistently be applied to all forms of action challenging state or local tax collection.

\section{An Impact Approach to Section 1341 ,}

The judicial interpretation of the scope of section 1341 has exhibited a continuing development away from a rigid formalistic approach to the statute toward a more flexible impact approach. In cases seeking injunctive relief, this approach has led courts to apply the statute more narrowly than its liberal language when the effect of an injunction would be to augment rather than restrict state or local tax collection and expansively when the requested relief would not directly enjoin a tax, but would indirectly disrupt its collection. In actions requesting declaratory judgments against such taxes, many courts, supported by the Great Lakes dictum, have found that the Tax Injunction Act's policy of avoiding interference with state and local tax collection mandates application of section 1341 . The courts that have analyzed the issue have justified this expansive reading of the statutory language by noting that the impact of a

134 The test in Euangelical Catholic Communion, see text and notes at notes 115-118 supra, on the other hand, appears to sweep more broadly than Congress ever intended. Since state-law refund suits involve adjudication of the validity of the challenged tax, by the court's reasoning, such suits would be conditionally barred in federal court by section 1341-a result that is at odds with the legislative intent. See text and notes at notes 55-57 supra. 
declaratory judgment is indistinguishable from that of an injunction. The cases concerning actions for monetary judgment test the extent to which section 1341 should be construed to implement its policy of noninterference. Although no consistent theory of section 1341 can explain the results in the various actions for monetary relief, the cases do generally evidence an impact-oriented approach to the statute that rejects any distinctions between equitable and legal relief. That such an impact approach will emerge as the accepted method of determining the applicability of section 1341 seems inevitable from the developing case law.

A principled and workable impact test must be based upon a firm understanding of the policy concerns that motivated the enacting Congress. The body of case law construing section 1341 in the context of damage actions has not consistently demonstrated such an understanding. The courts' failure to elaborate clearly and consistently the contours of an impact approach prevents the effective application of section 1341. A test more consonant with the legislative objective underlying the Tax Injunction Act would provide that actions for money damages related to the imposition of state or local taxes are barred by section 1341 if the damages are attributable to the attempted collection of a currently owed tax and if judgment for the plaintiff would require judicial determination of the validity of the tax.

Although this proposed test departs from the refund focus of Bland, it would effectuate the congressional purpose evidenced in the legislative history of section 1341 . Congress, in enacting the Act of 1937, was not concerned with all federal interference with state and local taxation, but only with taxpayers litigating the validity of their taxes prior to payment. ${ }^{135}$ The consequence of avoiding the states' pay-before-you-litigate procedures was disruption of the continuity of their tax collection, and in many cases injury to their fiscal integrity. An injunction obtained in federal court is almost certain to cause such disruption. As the Great Lakes Court concluded, declaratory judgments would be likely to produce the same practical impact. Not all actions for monetary judgment, however, produce such a disruptive impact. Indeed, in most instances-and always with state-law refund suits and refund-type damage actions-the taxes have been collected, and consequently the continuity of tax collection will not be interrupted. ${ }^{136}$ But when the taxes

135 S. Rep. No. 1035, 75th Cong., 1st Sess. 1-2 (1937).

136 Although the action is not barred in federal court by section 1341 , the court may still decline to exercise jurisdiction under the doctrine of judicial abstention. See generally Note, 
have not been collected, and entertainment of a tax-related damage action would require a judicial determination of the validity of the $\operatorname{tax},{ }^{137}$ the implicit adjudication of the tax's validity would be indistinguishable from a declaratory judgment.

Defining the impact test narrowly to comport with the "continuity" objective appears to entail at least one difficulty. A multiplicity of actions might ensue from applying section 1341 to claims for injunctive relief, but not to all claims seeking legal relief. ${ }^{13 \mathrm{~K}}$ Treating legal claims differently from injunctive ones may result in a bifurcation of remedies: a plaintiff might be able to bring his claim for a refund in the federal courts, yet have his injunctive claim, even though part of the same action, precluded by section 1341. A broader impact test could avoid such multiplicity of actions by expanding section 1341's applicability to all legal actions. But the uniformity and judicial economy of such a broad test could be achieved only at the cost of disregarding the legislative intent. ${ }^{139}$ The gain would, moreover, be small. Since many state tax procedures make it difficult or impossible to obtain injunctive relief from a tax in state court, ${ }^{140}$ federal court consideration of a refund or refund-

supra note 102. Whether judicial abstention is proper outside of equity is uncertain, since the discretion to abstain from exercising federal jurisdiction arises from the equitable power of the judge. See Clark v. Lutcher, 436 F. Supp. 1266, 1271 (M.D. Pa. 1977); cf. Great Lakes Dredge \& Dock Co. v. Huffman, 319 U.S. 293, 300 (1963) (abstention in a declaratory action is permissive because of the equitable nature of the action). Although some courts have stated that judicial abstention is limited to equitable actions, see, e.g., Baltimore Bank for Coops. v. Farmers Cheese Coop., 583 F.2d 104, 111 (3d Cir. 1978); Clark v. Lutcher, 436 F. Supp. 1266, 1271-72 (M.D. Pa. 1977), the Supreme Court seemed to endorse its use in a legal action in Clay v. Sun Ins. Office, Ltd., 363 U.S. 207 (1960). And several courts have applied abstention doctrines to tax-related damage actions. See, e.g., Kistner v. Milliken, 432 F. Supp. 1001, 1004-05 (E.D. Mich. 1977) (reasoning that the abstention principles of Matthews v. Rodgers, 284 U.S. 521 (1932), and Great Lakes Dredge \& Dock Co. v. Huffman, 319 U.S. 293 (1943), were equally applicable to refund actions); Varian Assocs. v. County of Santa Clara, 317 F. Supp. 888 (N.D. Cal. 1970) (applying Pullman-type abstention, see Railroad Comm'n v. Pullman, 312 U.S. 496 (1941), to allow state court to resolve issues of state law that may be dispositive).

${ }_{137}$ See, e.g., Evangelical Catholic Communion, Inc. v. Thomas, 373 F. Supp. 1342 (D.

Vt. 1973), aff'd mem., 493 F.2d 1397 (2d Cir. 1974).

13s See Mandel v. Hutchinson, 336 F. Supp. 772, 780 (C.D. Cal. 1971), aff'd, 494 F.2d 364 (9th Cir. 1974).

139 See text and notes at notes 55-57 supra.

iso See, e.g., Ariz. Rev. Stat. AnN. § 42-204(B) (1956); Cal. Const. art. 13, § 15; D.C. Code Encycl. $\$ 47-2410$ (West 1968); Ga. Code AnN. \$ 92-6413 (Supp. 1978); Ill. Rev. Stat. ch. 120, $\$ 675$ (Supp. 1979); Mich. Comp. Laws AnN. § 211.114 (1967); OkLA. Stat. Ann. tit. 68 , 24342 (West 1966); S.C. CODE \& 12-47-10 (1976); S.D. CoMp. Laws ANN. § 10-27-1 (1967); TEnn. Code Ann. § 67-2311 (1976); Utah Code Ann. § 59-11-14 (1974); VA. Code § 58-1158 (1974). 
type damage action will not, in most cases, result in a multiplicity of actions.

A countervailing consideration to applying section 1341 broadly to all damage actions is the potentially debilitating impact such an application could have on the effectiveness of section 1983 in the context of state and local taxation. Section 1983 was intended to facilitate the redress of constitutional deprivations by providing access to the more objective federal forum. ${ }^{141}$ But the courts have consistently held that section 1341 bars section 1983 suits seeking injunctions against state or local taxes. ${ }^{142}$ The Tax Injunction Act creates an exception to section 1983 , not the reverse. ${ }^{143}$ If section 1341 operates to bar damage actions having an impact on state tax collection, then section 1983 damage actions also are subject to that bar. Although a taxpayer may still pursue his section 1983 remedy in the concurrent jurisdiction of the state courts, ${ }^{144}$ the ability to

14 See Mitchum v. Foster, 407 U.S. 225, 242 (1972).

112 E.g., King v. Sloane, 545 F.2d 7 (6th Cir. 1976) (per curiam); Hickmann v. Wujick, 488 F.2d 875 (2d Cir. 1973) (per curiam); American Commuters Ass'n, Inc. v. Levitt, 279 F. Supp. 40 (S.D.N.Y. 1967), aff'd, 405 F.2d 1148 (2d Cir. 1969); see 17 C. WriGHT, A. MiLLER \& E. Cooper, supra note $2, \$ 4237$, at 427.

it3 See 17 C. WRIGHT, A. MiLLER \& E. CoOpER, supra note $2, \S 4237$, at $427 \&$ n. 40 . In Mitchum v. Foster, 407 U.S. 225 (1972), the Supreme Court held that section 1983 constitutes an "expressly authorized" exception to the anti-injunction statute, 28 U.S.C. $\$ 2283$ (1976). 407 U.S. at 242-43. Although section 2283, unlike section 1341, specifies exceptions to its bar on suits to enjoin state judicial proceedings, the analogy between the two jurisdictional limitations is stronger than the statutory language suggests. The predecessor to the current anti-injunction statute existed for over 150 years without any statutory exceptions. See Mitchum v. Foster, 407 U.S. at 231-32. Yet, the courts found exceptions where necessary "if the import and purpose of other Acts of Congress were to be given their intended scope." Id. at 234-35 (citing cases). Such an exception to section 1341 could seemingly be found in light of section 1983's purpose of protecting federal rights from deprivation at the hends of state and local officials. In state fiscal matters, the state courts could be deemed particularly suspect in ensuring vindication of federal rights. The Court recently declined to address a district court's entertainment, notwithstanding section 1341, of a constitutional challenge to a state tax brought under the civil rights jurisdictional provision, 28 U.S.C. $\$ 1343(3)$ (1976). Moe v. Confederated Salish \& Kootenai Tribes, 425 U.S. 463, 475 n. 14 (1976).

i' See Long v. District of Columbia, 469 F.2d 927, 937 (D.C. Cir. 1972); International Prisoners' Union v. Rizzo, 356 F. Supp. 806, 810 (E.D. Pa. 1973); 90 HaRv. L. REv. 616, 623 n.49 (1977). See generally Testa v. Katt, 330 U.S. 386 (1947); HART \& WECHSLER, supra note 3, at 434-38, 521-24; Note, State Enforcement of Federally Created Rights, 73 Harv. L. REv. 1551 (1960). The extent to which a state court entertaining a section 1983 action would be compelled to grant the same relief as a federal court and the extent to which state procedural requirements can limit such an action are uncertain. See C. WrIGHT, supra note $3, \S 45$, at 193-96; cf. Sullivan v. Little Hunting Park, Inc., 396 U.S. 229, 238 (1969) ("federal remedy for the protection of a federal right [section 1982] is available in the state court, if that court is empowered to grant injunctive relief generally").

That state courts have concurrent jurisdiction over section 1983 claims does not undermine the policies that prompted enactment of the Tax Injunction Act. First, disruption of state or local taxing processes by a section 1983 suit in state court may be mitigated by 
recover in state court is likely to be more difficult ${ }^{145}$ and the amount of recovery may be smaller than in the more congenial federal forum..$^{146}$

Because the legislative policy underlying section 1341 requires an impact approach that encompasses damage as well as injunctive actions, it would be incongruous to create an exception from section 1341 for section 1983 damage actions only. Courts nevertheless should be reluctant to construe section 1341's jurisdictional bar broadly when it impinges on the section 1983 cause of action. This reluctance would not be dispositive when damages are sought before taxes have been paid, for an adjudication of the action would implicate section 1341's policies by interfering with state tax collection. The reluctance to bar civil rights actions is most appropriate when refund-type damage actions are at issue. Such actions are on the periphery of the Tax Injunction Act policies. Their close similarity to state-law refund actions, which Congress did not intend section 1341 to prevent, renders application of the section suspect from the outset. That such actions are not subject to the same restraints as state-law refund suits, particularly exhaustion of administrative remedies, and may be prosecuted against tax officials in their personal capacities does make such damage actions somewhat more intrusive on state tax administration. But an exhaustion requirement could be applied without adopting section 1341's complete bar. ${ }^{147}$ Moreover, making officials personally liable for civil rights

limitations on the form of relief available (for example, denial of interest or attorneys' fees) and restrictive procedural requirements (such as a provision for payment of taxes prior to suit challenging their collection). In particular, to the extent that pay-first-sue-later rules limit state-court section 1983 actions, such suits will have less of a chilling effect and less of an impact on the state's fiscal stability than a suit in federal court. Section 1983 was enacted in part because Congress feared that state courts might not redress adequately deprivations of constitutional rights by state officials. To argue that the impact of a section 1983 action brought in state court is the same as one brought in federal court seems to contradict that legislative history. Second, nothing in the legislative history of section 1341 suggests that it was to be limited to those actions that could be brought in federal but not state court. Even in those cases in which a state court will entertain a suit that restrains, hinders, or even enjoins a state tax, federalism concerns militate against federal jurisdiction over such suits. State courts are more likely to be sensitive to the peculiar needs of the state treasury and to adjudicate challenges to state taxes accordingly. Judicial interference with matters as crucial to the integrity of the state as taxation is appropriately imposed by state, rather than federal courts.

145 See Mitchum v. Foster, 407 U.S. 225, 240-42 (1972) (section 1983 enacted in response to concern that state courts would not adequately enforce rights under fourteenth amendment).

148 In particular, interest on tax payments refunded and attorneys' fees may not be available in state courts. See, e.g., Fulton Mkt. Cold Storage Co. v. Cullerton, 582 F.2d 1071, 1080 (7th Cir. 1978), cert. denied, 99 S. Ct. 1033 (1979).

117 See Note, supra note 102, at 305-09. 
violations is squarely within the purpose of section $1983 .{ }^{148}$ Any attenuated and hypothetical impact such personal liability might have on state tax administration is not so close to the core of section 1341's policy as to justify a restriction of section 1983 .

Application of the test to actions for monetary judgment would not require searching analyses by federal judges. A judge need only ascertain whether the disputed taxes have been paid and whether relief would require a judicial determination of the validity of the impositions. Application of this narrow impact test in Bland and Evangelical Catholic Communion would have resulted in the courts holding section 1341 inapplicable to those refund-type damage claims. The claim for additional damages in Evangelical Catholic Communion was similarly outside the scope of section 1341 , since it presumably sought redress for injuries attributable to taxes that had already been paid. The instances in which this impact approach will require application of section 1341 are very limited. One case in which the result would have been unchanged under the proposed test is Advertiser Co. Damages in that case were sought for the attempted collection of taxes. For the district court to have entertained that action would have required a determination of the validity of the disputed taxes prior to their payment-exactly what the framers of section 1341 wanted to avoid.

The proposed impact test will only infrequently require an application of section 1341 to actions for monetary judgment: it is rare that damages sought are attributable to a tax imposition prior to its collection or payment. Adoption of the test will in most instances produce the same result-finding section 1341 inapplicable-that would obtain if the section were narrowly construed as inapplicable to all legal actions. But the few instances in which section 1341 will apply are the most important: those claims that destroy the vitality of the Act by permitting implicit judicial determinations of the validity of a tax prior to its payment.

\section{Conclusion}

The legislative history of section 1341 reflects a congressional intent to protect the continuity of state and local tax collection from disruptive interference by suits in federal courts. For this congressional objective to be fully realized, the statute should be read as governing both equitable and legal actions when their adjudication could interfere with the processes of state or local taxation. The

14 See Monroe v. Pape, 365 U.S. 167, $171-72$ (1961); Developments, supra note 7, at 1154. 
cases construing section 1341, which have frequently focused on the impact rather than the form of the action, underscore this broad reading of the statute. In several instances, courts confronted with requests for tax-related injunctions have looked beyond the form of the action to ascertain what the impact of the injunction would be. And in Great Lakes Dredge \& Dock Co. v. Huffman, the Supreme Court cited the policy behind section 1341 as requiring the federal courts to abstain from granting declaratory relief from state taxes if state remedies were adequate to give relief to aggrieved taxpayers. Many lower courts subsequently adopted this rationale in applying section 1341 to declaratory judgment actions.

The judicial treatment of the growing number of state and local tax-related actions for monetary judgments brought in the federal courts reflects the impact orientation of the injunction and declaratory-judgment cases. A majority of the courts have applied section 1341 to damage actions because of the impact such actions have on state tax administration. Many courts, however, have gone too far. The emerging impact approach for actions seeking monetary judgment requires further refinement and modification. A principled impact approach must have as its foundation a goal of nondisruption of the continuity of state and local tax collection. Rather than barring all federal interference with state and local tax collection, a result the legislative history strongly suggests Congress did not intend, a narrower impact approach would result in applying section 1341 only to those damage actions that disrupt the continuity of revenue collection by requiring a determination of the tax's validity prior to payment. Adoption of such an approach to actions seeking monetary relief would thus ensure the consistent application of section 1341, regardless of the form of an action, and the furtherance of the congressional objectives underlying the section. 